\title{
Corporate Board Diversity and Financial Performance: The Nigerian Insurance Sector's Perspective
}

\author{
Gbarato, Ledum Moses
}

Finance $\&^{\circ}$ Banking Department, University of Port Harcourt, Port Harcourt, Nigeria. Email:_ledum4success@gmail.com Tel:2348063104473

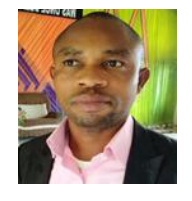

\begin{abstract}
The presence of appropriate gender diversity, board size and board composition does not only promote favourable organizational ambience but also offers meaningful upsurge in the financial position of an organization relatively. It is on this premise that prompted the essence to examine the relationship between corporate board diversity and financial performance of insurance companies in Nigeria for the period 2014 to 2018. Secondary data from Cornerstone Insurance Plc. and Lasaco Assurance Plc. were employed in the study. Using the Panel least Square regression technique, the results reveal that gender diversity, board size and board composition exert insignificant influence on profit before tax as the measure of financial performance. However, while gender diversity exerts negative influence, board size and board composition exert positive influences on profit before tax of insurance companies. The study concludes that employment of appropriate number of directors and also in suitable composition as board members have positive effect on the financial performance of insurance firms. Therefore, the study recommended among others, that: appropriate ratio of executive to independent non-executive directors should be maintained among board members for better decision-making at the interest of all stakeholders. Also, the ratio of gender diversity (female to male directors) should be increased as the role of women in resource management cannot be relegated to the background especially in financial performance of insurance companies.
\end{abstract}

Keywords: Gender diversity, Board size, Board composition, Profit, Insurance companies, Nigeria.

Citation | Gbarato, Ledum Moses (2020). Corporate Board Diversity and Financial Performance: The Nigerian Insurance Sector's Perspective. Growth, 7(1): 20-25.

History:
Received: 17 April 2020

Revised: 25 May 2020

Accepted: 29 June 2020

Published: 20 July 2020

Licensed: This work is licensed under a Creative Commons

Attribution 3.0 License (cc)

Publisher: Asian Online Journal Publishing Group
Funding: This study received no specific financial support.

Competing Interests: The author declares that there are no conflicts of interests regarding the publication of this paper.

Transparency: The author confirms that the manuscript is an honest, accurate, and transparent account of the study was reported; that no vital features of the study have been omitted; and that any discrepancies from the study as planned have been explained.

Ethical: This study follows all ethical practices during writing

\section{Contents}

1. Introduction

2. Theoretical Underpinning..

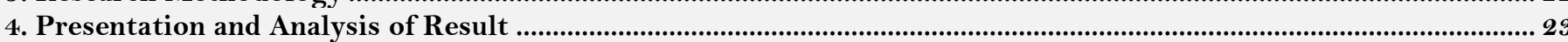

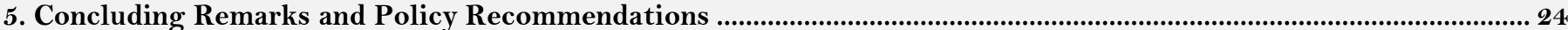

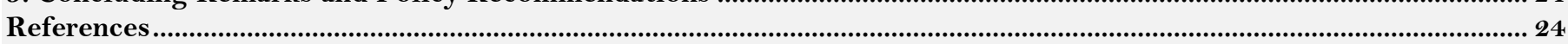




\section{Contribution of this paper to the literature}

As a contribution to knowledge, this paper unveils the prominence of the trio corporate board diversity - board composition, board size and gender diversity - to financial performance of organizations when appropriately structured.

\section{Introduction}

Every organization needs to continually recognize the critical role played by its board of directors in enhancing best corporate governance thus resulting in organizational performance (Oludele, Oloko, \& Tobiah, 2016). The corporate governance structure specifies the distribution of the rights and the responsibilities among different participants in the corporation, and spells out the rules and procedures for making decisions on corporate affairs. Such participants include the board, managers, shareholders and other stakeholders (Adesanmi, Sanyaolu, Isiaka, \& Fadipe, 2019). Corporate governance also provides the structure through which the company objectives are set, and the means of attaining those objectives and monitoring performance.

Agency theorists argue that in order to protect the shareholders' interests, the board of directors must assume an effective oversight function (Adesanmi et al., 2019). It is assumed that board performance of its monitoring duties is influenced by the effectiveness of the board, which in turn is influenced by factors such as board composition and quality, size of board, gender diversity, ethnic diversity and foreign directorship. The board of directors is one of the most influential decision-making bodies. Its responsibilities span from making key financial and strategic decisions, such as approving changes in capital structure and mergers and acquisitions, to the difficult task of choosing the company's top executive leadership (Ferreira \& Gyourko, 2014). The board is often noted as having four key functions: monitoring and controlling managers, providing information and counsel to managers, monitoring compliance with applicable laws and regulations, and linking the corporation to the external environment (Mallin, 2004; Monks \& Minow, 2004). Trend from the changes and reviews of corporate governance codes reveals that there is a need to continuously investigate characteristics of boards that will improve performance and reduce corporate failures and scandals (Adesanmi et al., 2019).

Trend from the changes and reviews of corporate governance codes reveals that there is a need to continuously investigate characteristics of boards that will improve performance and reduce corporate failures and scandals. For example, the Security and Exchange Commission (SEC) in 2003, put forward that, the financial sector attracted poor corporate governance due to the fact that, only about $40 \%$ of quoted companies, including insurance companies had recognized codes of corporate governance in place (Charles, Opemipo, \& Sunday, 2018). Consequently, in 2003, a Code of Best Practices on Corporate Governance for public quoted companies was released by the Nigerian Securities and Exchange Commission (SEC).

The Nigerian scenario suggests that there is a continuous need to look into board characteristics and identify what are essential for improved performance. Prior empirical studies on board characteristics have yielded different results (Hermalin \& Weisbach, 2003). Researchers in Nigeria (Adebayo, Ayeni, \& Oyewole, 2013; Adeusi, Akeke, Aribaba, \& Adebisi, 2013; Charles et al., 2018) have focused on characteristics such as board size, CEO duality, audit committee, and ownership structure. Very little attention has been given to board diversity in relation to gender diversity, board size, and board composition in relation to financial performance in the insurance sector, which now necessitates this study.

Therefore, this study sets out to empirically examine the relationship that subsists between gender diversity, board size, board composition and profit before tax of insurance companies in Nigeria.

\section{Theoretical Underpinning \\ 2.1. Stakeholder Theory}

By extension, the stakeholder theory borrows from the agency theory (Freeman, Wicks, \& Parmar, 2004). The theory articulates the role of board of directors as custodians of the shareholders' interests. Despite the narrow emphasis on shareholders as suggested by the agency theory (Freeman et al., 2004) the stakeholder theory introduces a change by theorizing that the board of directors is expected to be responsible for the interests of the several and diverse stakeholder groups. The groups will include all interest groups associated to the firm's social, political, environmental, and ethical realms (Donaldson \& Preston, 1995; Freeman et al., 2004; Freeman, 1984). The stakeholder theory as noted introduces a new role for the board of directors. As such, the theory highlights that firms and the society are interdependent and thus, the firm will function to serve a wider social intent than its responsibilities to shareholders/ owners or principals (Donaldson \& Preston, 1995). Stakeholder here is viewed as any party (individual or organization) who could influence or is influenced by the operations, strategies, and realization of the firm's objectives (Oludele et al., 2016). Consequently, business for an organization concerns establishing arrangements and deals so that customers, employees, communities, suppliers, managers and BODs and shareholders are better off progressively and over the long-term (Freeman et al., 2004).

However, numerous companies seek to maximize shareholder value while concurrently endeavoring to consider the interests of other stakeholders. Indeed, Rhode and Packel (2010) express that the intention of shareholder value maximization matters since it is through value maximization for shareholders that decisions and operations that result in outcomes for all stakeholders emanate.

\subsection{Agency Theory}

Agency theory is based on the fact that many corporate managers are not owners but agents of owners, contracted to manage the company on their behalf (Ujunwa, Nwakoby, \& Ugbam, 2012). The board of directors is one of several important mechanisms that control and monitor managers and plays a vital role in the managerial policies of the companies (Fama \& Jensen, 1983). The board of directors aims to solve agency problems between managers and shareholders (Dang, Nguyen, \& Vo, 2013). Based on this theory, the presence of women and foreign directors will increase the board's effectiveness and firm performance. The basic premise is that diversity may lessen the tendency for boards to engage in groupthink (Ujunwa et al., 2012). Agency theorists also indicate that 
having women, ethnic minorities, and foreigners as external stakeholders may bring fresh solutions to complex issues (Francoeur, Labelle, \& Sinclair-Desgagné, 2007). For instance, female directors might be more active in monitoring and controlling managers by asking more questions and bringing different perspectives to the boardroom (Dang et al., 2013). Furthermore, diversity will increase board independence because people with a different gender, ethnicity, or cultural background might ask questions that would not come from directors with traditional backgrounds (Carter, D'Souza, Simkins, \& Simpson, 2008; Carter, D'Souza, Simkins, \& Simpson, 2010). Hence, diverse boards will improve firm performance by increasing board independence.

\subsection{Empirical Review}

In recent years, issues related to elements of corporate board diversity has attracted great attention in corporate governance considering their effect on firm performance. This sections showcases some of the attentiongrabbing extant literature that examine the relationships among gender diversity, board size, board composition and organization performance. Ujunwa et al. (2012) investigates the impact of corporate board diversity on the financial performance of Nigerian quoted firms using a panel data of 122 quoted Nigerian firms (1999-2008). Employing the Fixed Effect Generalised Least Square Regression on board nationality, board gender and board ethnicity in relation to financial performance, the findings reveal that gender diversity was negatively linked with firm performance, while board nationality and board ethnicity were positive in predicting firm performance. The study provides insights for practitioners and policy makers on the need to view the board as a strategic resource in line with the resource dependency theory instead of viewing the board solely from agency theory perspective. Oludele et al. (2016) assert that there is a significant positive linear relationship between board gender diversity and financial performance of listed manufacturing companies in Nigeria. Their study which focus on 34 manufacturing companies selected for the study, used primary data retrieve from 170 respondents drawn from the selected 34 companies. The study thus recommends that manufacturing companies in Nigeria should increase the ratio of women to men in their board of directors. Female directors are likely to possess support/ staff managerial skills such as human resources, legal, public relations, communications, as opposed to line functions of operations, marketing, compared to men. Alabede (2016) employing OLS multiple regression to analyses firms' annual data on the relationship between internal corporate governance structures and firm performance and how this relationship is moderated by the influence of board diversity found that the proportion of outside directors, board size, board diversity are significantly positively related to operating performance (ROA). The empirical evidence also indicates that the moderating effect of board diversity strengthens the relationship between outside directors and operating performance as well as between board size and operating performance. By implication, the result suggests that Agency Theory must explicitly indicate that board diversity plays important moderating role in corporate governance. Otuya, Donwa, and Egware (2017) examination of the effect of banks' board globalizing on financial performance of quoted banks in Nigeria shows that foreign board membership, asset growth and institutional ownership have a significant positive relationship with financial performance of banks, using ordinary least square (OLS) regression as the basic techniques of data analysis on secondary data (2011-2015). In the work of Pere and Obah (2018) board size, leverage and Audit Committee were used to proxy corporate governance in relation to financial performance of Nigeria insurance industry. The study employed secondary data from the Mutual Benefits, FBN Life, and Zentih Life Insurance Annual Financial Reports from 2005 to 2015. The results of multiple regressions analysis established that Board Size and Audit Committee have significant impact on profit before tax of insurance companies in Nigeria, while leverage does not have significant impact on profit before tax of insurance companies in Nigeria. The study therefore recommends that Nigerian Insurance Industry through the respective authorities should properly define corporate governance and its mechanisms and implement them effectively to reach the firm's long-term goals, build stakeholders' confidence and generate positive investment flows. Charles et al. (2018) also investigated the relationship between corporate board diversity and performance of quoted deposit money banks in Nigeria. Proxying corporate diversity with gender diversity, ethnic diversity, board composition, and foreign directorship in relation to Return on asset (ROA) for the period 2011 to 2015. The results from fixed effect Generalized Least Square Regression analysis revealed that gender diversity and board composition were positively linked to financial performance, while ethnic diversity and foreign directorship were not significantly related to financial performance. The results also revealed that ethnic diversity is positively related to market performance, while board composition and foreign directorship are negatively related to market performance. The study recommends among other things, that there should be more representation of female directors on corporate boards and that hiring of foreign directors should be discouraged by Deposit Money Banks in Nigeria.

A survey of the extant empirical literature on corporate board diversity showed that most of the accessed studies were on the banking and manufacturing sectors of the economy. Also, most of these studies were crosscountry studies. However, that of Pere and Obah (2018) that is Nigerian based ended its study period at 2015. In light of this backdrop, this study intends to fill existing gap by assessing the effect of corporate board diversity in terms of gender diversity, board size and board composition on the performance of insurance companies in Nigeria.

\section{Research Methodology}

This research design employed is the ex-post facto design which seeks to establish the cause-effect relationship and the variables of interest and data for the empirical study are secondary data sourced from the Cornerstone insurance Plc. and Lasaco Assurance Plc. annual financial reports from 2014 to 2018. The statistical technique adopted for this study is panel multiple regression econometric procedure with the aid of E-view (version 10) software. The t-test was employed to ascertain the significance of each of the constant parameters, while the diagnostic test based on the coefficient of determination $\left(\mathrm{R}^{2}\right)$ was used to check for the goodness of fit of the model. The Durbin-Watson statistic was employed also to measure the serial correlation in the residuals.

In line with our objectives, we employed a multiple regression in analyzing the relationship between Corporate Board Diversity and Financial Performance of Insurance companies in Nigeria. While Profit before tax is used to measure financial performance (the explained variable), Gender Diversity, Board Size and Board Composition are 
used to proxy Corporate Board Diversity (the explanatory variable) of insurance companies in Nigeria. Borrowing from the model of Pere and Obah (2018) with little modification, the functional relationship is given as:

Financial Performance $=\mathrm{f}($ Corporate Board Diversity $)$

$$
\mathrm{PBT}=\mathrm{f}(\mathrm{GD}, \mathrm{BS}, \mathrm{BC})
$$

The equation is transform into econometric form as:

\section{Where:}

$$
\mathrm{PBT}=\beta_{\mathrm{o}}+\beta_{1} \mathrm{GD}+\beta_{2} \mathrm{BS}+\beta_{3} \mathrm{BC}+\mu
$$

PBT $=$ Profit before Tax.

GD $=$ Gender Diversity, computed as ratio of female to male amongst board of directors

BS = Board Size, calculated as number of people that make up corporate board.

$\mathrm{BC}=$ Board Composition, calculated as the number of independent non-executive directors on the board relative to the total number of directors.

$\beta \mathrm{O},=$ constant parameter.

$\beta \mathbf{1}, \beta \mathbf{2}, \beta \mathbf{3}=$ Coefficients or Parameters.

$\mu=$ error term.

A priori Expectation: $\beta_{1}>0, \beta_{2}>0, \beta_{3}>0$

\section{Presentation and Analysis of Result}

This section lays out the analysis and presentation of data used in the study. The panel least square technique was employed in the analysis after examining the behavior of the variable with the aid of descriptive statistics.

\subsection{Panel Descriptive Statistics}

\begin{tabular}{c|c|c|c|c}
\multicolumn{5}{c}{ Table-1. Panel descriptive statistics of cornerstone insurance \& lasaco assurance companies. } \\
\hline Statistics Tools & PBT & GD & BS & BC \\
\hline Mean & 1071888. & 0.474000 & 21.20000 & 0.868000 \\
\hline Median & 1563546. & 0.510000 & 23.00000 & 0.910000 \\
\hline Maximum & 4242753. & 0.600000 & 26.00000 & 1.040000 \\
\hline Minimum & -2572245. & 0.290000 & 16.00000 & 0.610000 \\
\hline Std. Dev. & 2568168. & 0.114586 & 4.438468 & 0.172395 \\
\hline Skewness & -0.271789 & -0.768860 & -0.243969 & -0.582067 \\
\hline Kurtosis & 2.021803 & 2.540783 & 1.324706 & 1.969806 \\
\hline Jarque-Bera & 0.260905 & 0.536555 & 0.634311 & 0.503439 \\
\hline Probability & 0.877698 & 0.764696 & 0.728217 & 0.777463 \\
\hline Sum & 5359441. & 2.370000 & 106.0000 & 4.340000 \\
\hline Sum Sq. Dev. & $2.64 \mathrm{E}+13$ & 0.052520 & 78.80000 & 0.118880 \\
\hline Observations & 5 & 5 & 5 & 5 \\
\hline
\end{tabular}

Table 1 reveals the various behavioural trends in the employed variables (profit before tax, gender diversity, board size, and board composition).

Mean: Profit before tax (PBT) and Board Size (BS) have greater mean values of 1071888 and 21.20000 respectively, while Gender Diversity (GD), and Board Composition (BC) with mean values of 0.474000, and 0.868000 respectively. However, only BS stands greater amongst the explanatory variables. From this statistics, it suggests the vital role of board size to organization's financial performance, as major decisions and policies are determined by board of directors.

Standard Deviation: In this measure of dispersion, board size is greatly leading. This suggests its dominant and high level of associated risk as a determinant of financial performance. However, gender diversity happens to portray the least standard deviation which attests the low associated risk in relation to financial performance of the selected insurance companies.

\subsection{Data Analysis}

The Ordinary Least Square (OLS) is employed as the technique for the analysis. This technique will help to reveal the relationship that prevails between the explanatory variables and explained variable in the short run. The data were transformed with the aid of taking logarithm of the data series. This enhance the quality of the data, thereby producing a dependable prediction of the relationship. Taking log on all the explanatory variables' data was necessary, taking into consideration that all the series were not in one unit measurement which calls for this data transformation.

Table-2. Panel least square result.

\begin{tabular}{c|c|c|c|c}
\hline Variable & Coefficient & Std Error & t-Statistic & Prob \\
\hline C & -39243205 & 19516376 & -2.010783 & 0.2938 \\
\hline LNGD & -12281584 & 4402986. & -2.789376 & 0.2191 \\
\hline LNBS & 10196887 & 5598485. & 1.821365 & 0.3196 \\
\hline LNBC & 931290.2 & 4052842. & 0.229787 & 0.8562 \\
\hline $\mathrm{R}^{2}=0.887793$ & F-stat $=2.637368$ & Prob $=0.000385$ & DW stat $=2.491284$ \\
\hline
\end{tabular}

A priori expectations are that gender diversity (GD), board size (BS) and board composition (BC) should exert positive influence on profit before tax (PBT).-From the Panel Least Square results shown in Table 2, coefficient of determination $\left(\mathrm{R}^{2}\right)$ for the model is 0.887793 indicating the strength of the independent variables to explain changes/variations that take place in the dependent variable. It implies that, the independent variables explain or account for 88.8 percent of variation in the dependent variable. That is, $88.8 \%$ of the variations in PBT is explained 
by the GD, BS and BC. In other words, about 11.2 percent of variation in the dependent variable is caused by other factors not included in the model.

The robustness of this result is further buttressed by an F-statistic of 2.637368 while the Durbin-Watson statistic of 2.491284 clearly indicates that there is no effect of serial correlation among the variables used in the study. With the Probability of F-statistic of 0.000385 , it is significant enough to conclude that the model has performed well.

All the explanatory variables exert insignificant relationship with Profit before Tax. However, while the coefficient of Gender Diversity assumes a negative value, that of Board Size and Board Composition assume positive values. This implies that one percentage point rise in Gender Diversity retards PBT by $122.8 \%$. This indicates that increase in profit of the selected insurance companies is not traceable to the gender diversity of the board of directors as at the period of study. This outcome of the study negates the a priori expectation as well as the finding of Charles et al. (2018) whose result showed that gender diversity was positively linked to financial performance. This suggests negligence of appropriate number of female directors needed amongst the board of directors because the role of women in the family cannot be over-emphasized for the success of the family as they are good managers of resources and make decisions that effect on the family positively.

Board Size and Board Composition positive relationships with PBT is normal. This is because, on one hand, increase in board size of directors suggests increase in human capital accompanied with diverse wealth of knowledge needed for optimum strategic decision-making devoid of sentiment and personal interest as may be found among lower board size. Although, a very large board size is not recommendable just as a small board size (Alabede, 2016) however, the nature of business operations inform the number of the board size in respect to their contributions.

Also, the positive influence of Board Composition on Profit before Tax shows that number of independent nonexecutive directors on the board relative to the total number of directors is in favour of financial performance (profit before tax) of the selected insurance companies. This suggests that non-executive directors can play an important role in the effective resolution of agency problems and their presence on the board can lead to more effective decision-making capable of enhancing the financial performance of the selected insurance companies.

These findings although insignificant, supported the works of Charles et al. (2018); Pere and Obah (2018) whose findings reveal that board size and board composition were positively linked to financial performance of financial institutions (banks and insurance companies) in Nigeria.

\section{Concluding Remarks and Policy Recommendations}

The study investigated the effect of corporate board diversity on financial performance of insurance companies in Nigeria. The study has found that there was an insignificant but positive relationship between board size, board composition and financial performance as at the study period (2014-2018). This implies that employment of appropriate number of directors and also in suitable composition as board members of insurance have positive effect on the financial performance of insurance. Based on the findings and conclusion from the study, in order to have a good corporate board diversity in the insurance sector, the study recommended that: appropriate ratio of executive to independent non-executive directors should be maintained among board members for better decision-making at the interest of all stakeholders. Also, the ratio of gender diversity (female to male directors) should be increased as the role of women in resource management cannot be relegated to the background especially in financial performance of insurance companies.

\section{References}

Adebayo, O. S., Ayeni, G. O., \& Oyewole, F. A. (2013). Relationship between corporate governance and organizational performance. International Journal of Business and Management Invention, 19(19), 1-16.

Adesanmi, A., Sanyaolu, O., Isiaka, M., \& Fadipe, O. (2019). Empirical analysis of board diversity and the financial performance deposit money banks in Nigeria. Accounting, 5(4), 127-134.

Adeusi, S. O., Akeke, N. I., Aribaba, F. O., \& Adebisi, O. S. (2013). Corporate governance and firm financial performance: Do ownership and board size matter? Academic Journal of Interdisciplinary Studies, 2(3), 251-251.

Alabede, J. O. (2016). Effect of board diversity on corporate governance structure and operating performance: Evidence from the UK listed firms. Asian Journal of Accounting and Governance, 7, 67-80.Available at: https://doi.org/10.17576/ajag-2016-07-06.

Carter, D., D'Souza, F. P., Simkins, B. J., \& Simpson, W. G. (2008). The diversity of corporate board committees and firm financial performance. Available at SSRN 972763.

Carter, D. A., D'Souza, F., Simkins, B. J., \& Simpson, W. G. (2010). The gender and ethnic diversity of US boards and board committees and firm financial performance. Corporate Governance: An International Review, 18(5), 396-414.Available at: https://doi.org/10.1111/j.1467-8683.2010.00809.x.

Charles, O., Opemipo, A. V., \& Sunday, E. O. (2018). Corporate board diversity and performance of deposit money banks in Nigeria. International Journal of Humanities and Social Science, 8(1), 112-120.

Dang, R., Nguyen, D. K., \& Vo, L. C. (2013). Women on corporate boards and firm performance: A comparative study. Retrieved from http://events.em-lyon.com/AFFI/Papers/252.pdf

Donaldson, T., \& Preston, L. E. (1995). The stakeholder theory of the corporation: Concepts, evidence, and implications. Academy of Management Review, 2O(1), 65-91.Available at: https://doi.org/10.2307/258887.

Fama, E. F., \& Jensen, M. C. (1983). Separation of ownership and control. The journal of law and Economics, 26(2), 301-325.

Ferreira, F., \& Gyourko, J. (2014). Does gender matter for political leadership? The case of US mayors. Journal of Public Economics, 112, 2439.Available at: https://doi.org/10.1016/j.jpubeco.2014.01.006.

Francoeur, C., Labelle, R., \& Sinclair-Desgagné, B. (2007). Gender diversity in corporate governance and top management. Journal of Business Ethics, 81(1), 83-95.

Freeman, R. E., Wicks, A. C., \& Parmar, B. (2004). Stakeholder theory and "the corporate objective revisited". Organization Science, 15(3), 364-369.

Freeman, R. E. (1984). Strategic management: A stakeholder approach. London: Pitman Publishing Inc.

Hermalin, B. E., \& Weisbach, M. S. (2003). Boards of directors as an endogenously determined institution: A survey of the economic literature. Economic Policy Review - Federal Reserve Bank of New Yo rk, 9(1), 7-26.

Mallin, C. A. (2004). Corporate governance. Oxford: Oxford University Press.

Monks, R., \& Minow, N. (2004). Corporate governance (Vol. 3). Malden, MA: Blackwell Publishing.

Oludele, O. I., Oloko, M. A., \& Tobiah, O. (2016). The impact of board gender diversity on the financial performance of listed manufacturing companies in Nigeria. International Journal of Economics, Commerce and Management, 4(12), 591-565. 
Otuya, S., Donwa, P., \& Egware, N. (2017). Earnings management and quality of corporate governance in Nigeria: A review of executive compensation and audit committee characteristics. Journal of Accounting and Financial Management, 3(3), 49-63.

Pere, S. D., \& Obah, O. D. (2018). Corporate governance and nigerian insurance industry. European Journal of Accounting, Finance and Investment, $4(11), 5-13$

Rhode, D. L., \& Packel, A. K. (2010). Diversity on corporate board: How much difference does differences make? Delawale Journal of Corporate Law, 39, 378-426.

Ujunwa, A., Nwakoby, I., \& Ugbam, C. O. (2012). Corporate board diversity and firm performance: Evidence from Nigeria. Corporate Ownership \& Control, 9(2), 216-236. 